\title{
Soluble interleukin-2 receptor in Crohn's disease: relation of serum concentrations to disease activity
}

\author{
J E Crabtree, L D Juby, R V Heatley, A J Lobo, D W Bullimore, A T R Axon
}

\begin{abstract}
Serum concentrations of soluble interleukin-2 receptor (sIL-2R) were measured as a marker of immune activation in a group of 30 patients with Crohn's disease. sIL-2R concentrations were determined by enzyme linked immunosorbent assay during periods of active and inactive disease and correlated with standard parameters of disease activity. Serum concentrations of sIL-2R were significantly raised in patients with active Crohn's disease compared with patients with inactive disease $(p<0.001)$ and control subjects. There was a significant correlation between serum sIL-2R concentrations and disease activity as assessed by the Harvey-Bradshaw index $(\mathrm{r}=0.42, \mathrm{p}<0.01)$, platelet numbers $(r=0.49, p<0.01)$, and orosomucoid $(r=0.47, p<0.01)$, alpha $a_{1}$ antitrypsin $(r=0.44, p<0.01)$, and $C$ reactive protein concentrations $(r=0.48, p<0.001)$ but not with the erythrocyte sedimentation rate. Measurement of serum sIL-2R concentration is a simple and useful laboratory means of assessing disease activity. Raised concentrations in patients with active Crohn's disease is further evidence for in vivo immune activation occurring in this disease.
\end{abstract}

Although the aetiology of Crohn's disease is unclear, both cellular and humoral immune phenomena are considered to play a part in the pathogenesis of the condition. ${ }^{1}$ The importance of $\mathrm{T}$ lymphocytes in regulating intestinal defences in Crohn's disease is well recognised. ${ }^{2}$ Both changes in immunoregulatory $T$ cell function ${ }^{34}$ and altered expression of molecular markers of $T$ cell activation on peripheral and mucosal lymphocyte populations have been described. ${ }^{56}$

Activation of resting $\mathrm{T}$ lymphocytes with specific antigen or mitogens results in the cell surface expression of interleukin-2 receptors (IL-2R). ${ }^{78}$ The binding of interleukin-2 to this high affinity receptor induces $T$ cell proliferation and a chain of immunological responses. ${ }^{7}$ The IL-2R is composed of at least two interleukin-2 binding polypeptides ${ }^{9}$ and in vitro studies have shown that after activation the $55000 \mathrm{M}_{\mathrm{r}}$ alpha chain, the Tac peptide, is released in a soluble form (sIL-2R). ${ }^{10}$ sIL-2R is detectable serologically in healthy people, and concentrations are raised in diseases associated with increased immune activation such as rheumatoid arthritis, ${ }^{11}$ sarcoidosis, ${ }^{12}$ parasitic infections, ${ }^{13}$ atopic eczema, ${ }^{14}$ and graft rejection. ${ }^{15}$ Recent studies have shown serum sIL-2R concentrations to be an excellent marker of gluten sensitivity in coeliac disease, with concentrations falling rapidly in response to gluten withdrawal. ${ }^{16}$
In Crohn's disease few well defined biochemical markers satisfactorily quantify disease activity, the disease being characterised by periods of activity and quiescence. As serum sIL-2R concentrations seem to indicate the extent of in vivo immune activation in various disease states, we investigated patients with Crohn's disease to determine whether serum sIL-2R concentrations reflect disease activity and examine the relation of sIL-2R to other standard assessments of disease activity.

\section{Methods}

\section{PATIENTS AND CONTROL SUBJECTS}

Thirty patients with Crohn's disease were studied (14 men, 16 women; mean (SE) age 33.9 $(2 \cdot 34)$ years). Twenty three of the patients were examined in both active and inactive phases of the disease. The diagnosis of Crohn's disease was based on standard clinical, endoscopic, histological, and radiological criteria. In 10 patients the disease affected both the ileum and the colon, in 10 patients the colon, and in 10 the small bowel. Twenty patients were receiving steroids (mean (SE) dose $14(2 \cdot 7) \mathrm{mg}$ ) and six azathioprine (mean (SE) dose $125(9.5) \mathrm{mg}$ ).

A control group of 18 healthy volunteers (10 women, eight men; mean (SE) age $39.6(3.4)$ years) was studied. A disease control group consisted of 13 patients (seven women, six men; mean (SE) age $43(3 \cdot 1)$ years), of whom 11 had an irritable bowel syndrome/motility disorder, one diverticular disease, and one rectal polypys.

Sera for sIL-2R measurement were stored at $-70^{\circ} \mathrm{C}$ until assayed. Collection of blood for other laboratory tests (C) reactive protein, erythrocyte sedimentation rate, platelet number, orosomucoid and $\alpha_{1}$ antitrypsin concentrations) was performed concurrently according to standard procedures.

\section{DETERMINATION OF DISEASE ACTIVITY}

Disease activity was assessed by the HarveyBradshaw index, which is based on a patient's well being, abdominal pain, number of liquid stools, presence of an abdominal mass, and extraintestinal manifestations, such as arthralgia and aphthous ulcers. ${ }^{17}$ This index correlates well with other more complex indices of disease activity. ${ }^{17}$

\section{ELISA FOR SIL-2R}

Serum sIL-2R concentrations were determined by an enzyme linked immunosorbent assay (ELISA) (T Cell Sciences, Cambridge MA) using two non-competing monoclonal anti- 


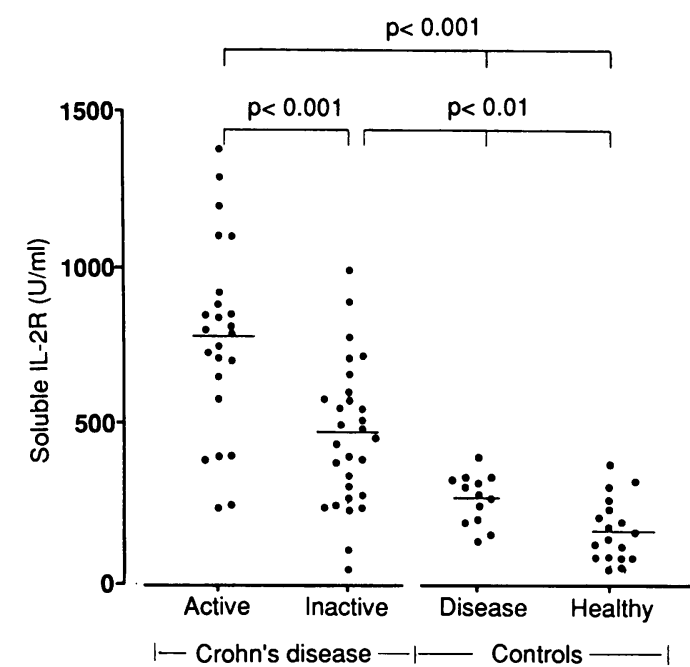

Figure 1: Serum sIL-2R concentrations in patients with active and inactive Crohn's disease, disease control subjects, and healthy control subjects.

bodies ${ }^{18}$ to the alpha chain of IL-2R, as described previously. "Microtitre plates (Nunc, Rosklide, Denmark) were coated with the monoclonal antibody 2R1.2, washed, and blocked. All samples were assayed in duplicate for $2 \mathrm{~h}$ at $37^{\circ} \mathrm{C}$. After washing, plates were incubated for $2 \mathrm{~h}$ with horseradish peroxidase-conjugated 7G7/B6 monoclonal antibody, which does not block IL-2 or anti-Tac binding to the IL-2R alpha chain. ${ }^{18}$ Bound antibody was detected using the substrate $O$-phenylenediamine and units of sIL-2R were determined from a standard curve of serial dilutions of supernatant from phytohaemagglutinin stimulated peripheral blood mononuclear cells ( $T$ Cell Sciences) defined as 1000 units $/ \mathrm{ml}$. Interassay variability was $7 \cdot 12 \%$ and the limits of sensitivity 50 units $/ \mathrm{ml}$.

The laboratory parameters of platelet number and erythrocyte sedimentation rate were determined using standard techniques. $C$ reactive protein, orosomucoid, and $\alpha_{1}$ antitrypsin concentrations were measured by radial immunoassay. ${ }^{19}$

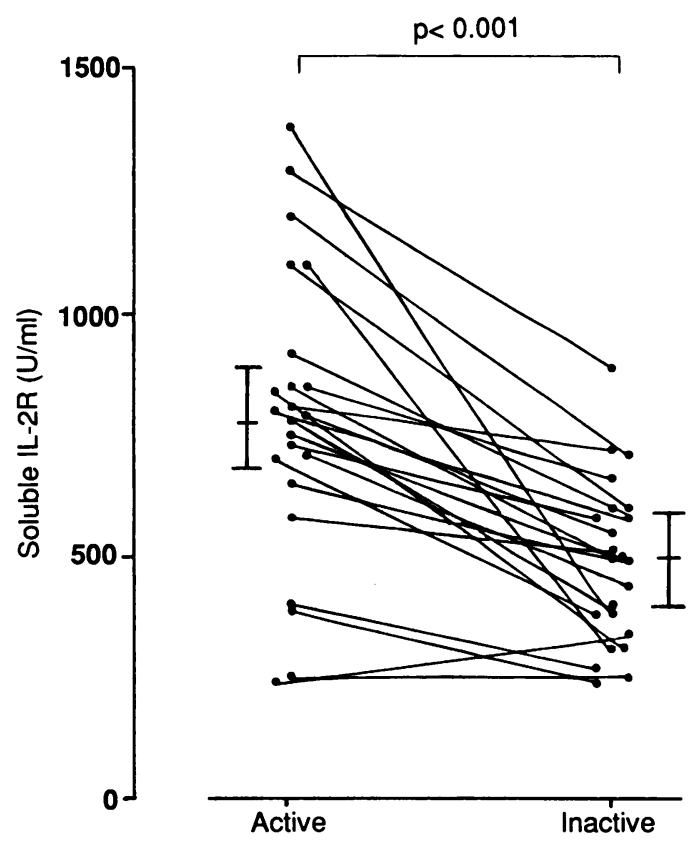

Figure 2: Serum sIL-2R concentrations in patients with Crohn's disease during active and inactive phases.
STATISTICAL ANALYSIS

Data are expressed as medians (SEM). Statistical comparisons were carried out using the KruskalWallis test, Mann-Whitney U test, Wilcoxon's signed rank test for paired data, and Spearman rank correlation coefficient.

\section{Results}

Serum concentrations of sIL-2R in patients with active (Harvey-Bradshaw index 5-13) and inactive (0-4) Crohn's disease and control groups are shown in Figure 1. The median (SEM) serum concentration of sIL-2R in the group of 24 patients with active Crohn's disease (785 (61.9)) was significantly greater $(\mathrm{p}<0.001)$ than that of healthy subjects $(160(22 \cdot 9))$ and disease control subjects $(280(21 \cdot 5))$. Five patients with active disease, however, had serum sIL-2R concentrations within the control range. The median serum sIL-2R concentrations in 29 patients with inactive Crohn's disease $(460(40 \cdot 3))$ was significantly lower $(p<0.001)$ than in patients with active disease, but greater than both control groups $(p<0.01)$. The serum sIL-2R concentrations in the disease control group were significantly greater $(p<0.01)$ than in the healthy control group.

Serum sIL-2R concentrations in patients with Crohn's disease examined during both active and inactive phases of disease activity are shown in Figure 2. Serum sIL-2R concentrations fell in all patients with high index scores of disease activity and raised sIL-2R concentrations who responded to treatment. In only two patients with a high clinical index, who were biochemically inactive (according to $\mathrm{C}$ reactive protein and erythrocyte sedimentation rate) was there no reduction in sIL-2R after reversion to a clinically inactive disease state.

There was a significant correlation between the serum sIL-2R concentrations and disease activity as assessed by the Harvey-Bradshaw index $(r=0.42, p<0.01, n=53)$ (Fig 3). In addition, there was a significant correlation between serum sIL-2R concentrations and platelet number $(\mathrm{r}=0.495, \mathrm{p}<0.01, \mathrm{n}=36)$ and orosomucoid $(r=0.474, p<0.01, n=45), \alpha_{1}$ antitrypsin $(\mathrm{r}=0.44, \mathrm{p}<0.01, \mathrm{n}=44)$, and $\mathrm{C}$ reactive protein concentrations $(r=0.485, p<0.001, n=$ $46)$, but not with the erythrocyte sedimentation rate $(r=0 \cdot 23, n=29)$. The Table shows the range and median values for $C$ reactive protein, $\alpha_{1}$ antitrypsin, and orosomucoid in the patients with active and inactive Crohn's disease.

\section{Discussion}

There is considerable evidence that Crohn's disease is associated with immune activation both in the intestinal mucosa ${ }^{2021}$ and systemically. ${ }^{6}$ Activation of $\mathrm{T}$ lymphocytes is accompanied by the cellular expression of the IL-2R (the Tac antigen) and, after immune stimulation in vitro, this receptor is shed from activated cells. ${ }^{10}$ The release of the IL-2R alpha chain, which occurs in proportion to its cell surface expression, allows assessment of in vivo immune activation by serological measurement of soluble IL-2R. 


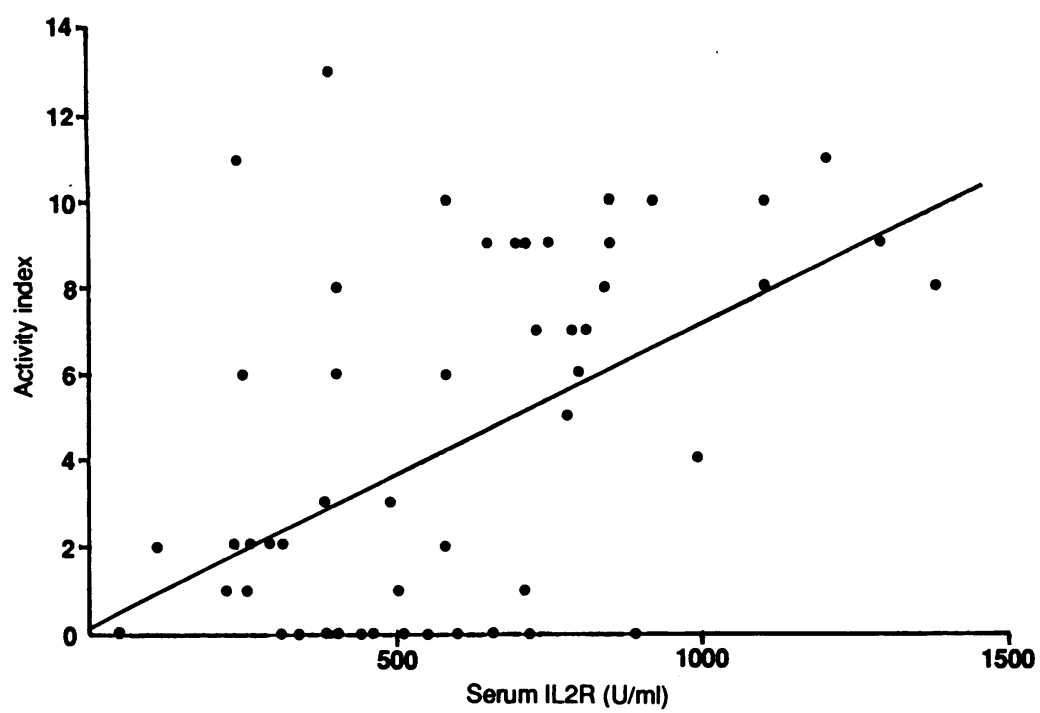

Figure 3: Relation between serum $I L-2 R$ concentrations and disease activity as assessed by the Harvey-Bradshaw index $(r=0.42, p<0.01)$.

The results of this study show that patients with active Crohn's disease have significantly raised serum sIL-2R concentrations and the circulating levels correlated well with disease activity as assessed by the Harvey-Bradshaw index. Even during inactive phases, sIL-2R values were raised in patients with Crohn's disease compared to control subjects. Although some studies have shown that clinical improvement in Crohn's disease is accompanied by a decrease in activated peripheral T cells expressing $\mathrm{T} 9$ (the transferrin receptor) and HLA/DR antigens, ${ }^{6}$ others have found persistence of early activation antigens on peripheral and intestinal mononuclear cells in quiescent phases of disease. ${ }^{5}$ The median serum sIL-2R concentration of the disease control patients was significantly greater than that of the healthy control group; however, no one in the former group had serum sIL-2R concentrations greater than 400 $\mathrm{U} / \mathrm{ml}$, the values being in the upper ranges of those of the healthy controls. The diagnosis in the disease control group was largely irritable bowel syndrome reached by excluding other serious disease.

Cellular expression of IL-2R is not restricted to cells of the $T$ cell lineage, as activated $B$ cells $^{22}$ and activated macrophages ${ }^{23}$ also express IL-2R. The cellular origin of the raised circulating sIL-2R concentrations in Crohn's disease is unclear. There seems to be no imbalance of immunoregulatory $T$ cell populations in the intestinal mucosa in Crohn's disease ${ }^{24} 25$; however, it has recently been shown that intestinal macrophages in inflammatory bowel disease express IL-2R. ${ }^{26}$ Whether macrophages release IL-2R in a similar manner to activated $B$ and $T$

Range and medians of acute phase reactants in patients with active and inactive Crohn's disease

\begin{tabular}{lcc}
\hline & Inactive $(n=24)$ & Active $(n=23)$ \\
\hline $\begin{array}{l}\text { Orosomucoid }(\mathrm{g} / \mathrm{l}) \\
\alpha_{1} \text { antitrypsin }(\mathrm{g} / \mathrm{l})\end{array}$ & $0 \cdot 67-3 \cdot 45(1 \cdot 33)$ & $0 \cdot 39-4 \cdot 58(2 \cdot 33)^{\star}$ \\
$\begin{array}{c}\text { C reactive protein } \\
(\mathrm{mg} / \mathrm{l})\end{array}$ & $<10-13(10)$ & $1 \cdot 99-10 \cdot 3(4 \cdot 68)^{\star}$ \\
\hline
\end{tabular}

${ }^{\star} \mathrm{p}<0.01 ; \mathrm{pp}<0.001$. cells $^{27}$ is unknown. The median (SEM) sIL-2R concentration in active Crohn's disease (785 $(61.9))$ was lower than that observed in untreated patients with coeliac disease $(1090(223)),{ }^{16}$ but clearly both of these intestinal inflammatory conditions are associated with increased immune activation, as assessed by serum sIL- $2 \mathrm{R}$ concentrations.

The lack of correlation of serum sIL-2R concentrations with the erythrocyte sedimentation rate is not altogether surprising since this is sometimes normal in patients with inflammatory bowel disease even when the disease is active. ${ }^{28}$ Serum sIL-2R concentrations were correlated, however, with other laboratory indices of disease activity including platelets, $\mathrm{C}$ reactive protein, $\alpha_{1}$ antitrypsin, and orosomucoid. This suggests that these parameters are directly related to the extent of immune activation and are not simply a reflection of the acute phase response. Recent studies have shown interleukin6 to be a major mediator of the acute phase response. ${ }^{29}{ }^{30} \mathrm{~A}$ relation between serum sIL-2R concentrations and platelet counts has also been observed in rheumatoid arthritis where sIL-2R concentrations were found to be an excellent monitor of clinical disease activity and to predict disease exacerbation. ${ }^{31}$

The results of this study suggest that serum sIL-2R measurements in patients with Crohn's disease may be a useful marker of disease activity, although current use is likely to be limited to clinical trials or research. Longitudinal studies could have a predictive value in relation to the onset of active phases of the disease.

Continued financial support from the National Association fo Colitis and Crohn's Disease is acknowledged. We thank Mis Sarah Walker-Merangh for her excellent technical assistance.

1 Heatley RV, Smart CJ, Danis VA. Inflammatory bowel disease. In: Losowsky MS, Heatley RV, eds. Gut defences in clinical practice. Edinburgh: Churchill Livingstone, 1986: 255-77.

2 Ferguson A. Why study T cell subsets in Crohn's disease? Gut 1983; 24: 687-91.

3 Elson CO, Graeff AS, James SP, Strober W. Covert suppressor T cells in Crohn's disease. Gastroenterology 1981; 80: 151321

4 James SP, Neckers LN, Graeff AS, Cossman J, Balch CM, Strober W. Suppression of immunoglobulin synthesis by Strober W. Suppression of immunoglobulin synthesis by
lymphocyte subpopulations in patients with Crohn's

5 Pallone F, Fais S, Squarcia O, Biancone L, Pozzilli P Biorivant $M$. Activation of peripheral blood and intestinal lamina propria lymphocytes in Crohn's disease. In vivo state lamina propria lymphocytes in Crohn's disease. In vivo state of activation and in vitro response to stimulation as defined $745-53$

6 Raedler A, Fraenkel S, Klose G, Seyfarth K, Thiele HG. Involvement of the immune system in the pathogenesis of Crohn's disease. Gastroenterology 1985; 88: 978-83.

7 Smith KA. Interleukin-2. Ann Rev Immunol 1984; 2 : 319-33.

Leonard WJ, Depper JM, Robb RJ, Waldmann TA, Greene WC. Characterization of the human receptor for $T$ cell W. Characterization of the human receptor for T cell

9 growth factor. Proc Natl Acad Sci USA 1983; 80: 6957-61 consequences of its bimolecular structure. $\mathcal{F}$ Exp Med 1987; 166: 1055-69.

10 Rubin LA, Kurman CC, Fritz ME, et al. Soluble interleukin-2 receptors are released from activated human lymphoid cells receptors are released from activated hum

11 Symons JA, Wood NC, Di Giovine FS, Duff GW. Soluble IL-2 receptor in rheumatoid arthritis: correlation with disease activity, IL-1 and IL-2 inhibition. F Immunol 1988; 141: 2612-8.

12 Lawrence EC, Berger MB, Brousseau KP, et al. Elevated serum levels of soluble interleukin-2 receptors in active pulmonary sarcoidosis: relative specificity and association with hypercalcemia. Sarcoidosis 1987; 4: 87-93.

13 Josimovic-Alasevic $\mathrm{O}$, Feldmeier $\mathrm{H}$, Zwingenberger $\mathrm{K}$, et al Interleukin 2 receptor in patients with localized and systemic parasitic diseases. Clin Exp Immunol 1988; 72: 249-54. 
14 Colver GB, Symons JA, Duff GW. Soluble interleukin 2 receptor in atopic eczema. $\mathrm{Br} M e d \mathcal{F}$ 1989; 298: 1426-8.

15 Adams DH, Wang L, Hubscher SG, Elias E, Neuberger JM Soluble interleukin-2-receptors in serum and bile of liver transplant recipients. Lancet 1989; i: 469-71.

16 Crabtree JE, Heatley RV, Juby LD, Howdle PD, Losowsky MS. Serum interleukin-2-receptor in coeliac disease response to treatment and gluten challenge. Clin Exp Immunol 1989; 77: 345-8.

17 Harvey RF, Bradshaw JM. A simple index of Crohn's disease activity. Lancet 1980; i: 514

18 Rubin LA, Kurman CC, Biddison WE, Goldman ND, Nelson DL. A monoclonal antibody $7 \mathrm{G} 7 / \mathrm{B} 6$, that binds to an epitope on the human IIL-2 receptor distinct from that epitope on the human IL-2 receptor distinct from that

19 Ingild A. Single radial immunodiffusion. Scand f Immunol 1983; 17: 41-56.

20 Mahida YR, Wu K, Jewell DP. Enhanced production of interleukin 1-beta by mononuclear cells isolated from mucosa with active ulcerative colitis or Crohn's disease. $G u$ 1989; 30: 835-8.

21 Mahida YR, Patel S, Gionchetti P, Vaux D, Jewell DP. Macrophage subpopulations in lamina propria of normal and inflamed colon and terminal ileum. Gut 1989; 30: 826-34.

22 Waldmann TA, Goldman CK, Robb RJ, et al. Expression of interleukin-2 receptors on activated B cells. $\mathcal{F}$ Exp Med 1984; 160: $1450-66$.

23 Hancock WW, Muller WA, Cotran RS. Interleukin-2 receptors are expressed by alveolar macrophages during pulmonary sarcoidosis and are inducible by lymphokin treatment of normal human lung macrophages, blood
monocytes, and monocyte cell lines. $f$ Immunol 1987; 138: monocytes,

24 Selby WS, Janossy G, Bofill M, Jewell DP. Intestinal lympho- cyte subpopulations in inflammatory bowel disease: an analysis by immunohistological and cell isolation techniques. Gut 1984; 25: 32-40.

25 James SP, Fiocchi C, Graeff AS, Strober W. Phenotypic analysis of lamina propria lymphocytes: predominance of helper-inducer and cytolytic T-cell phenotypes and deficiency of suppressor-inducer phenotypes in Crohn's disease and control patients. Gastroenterology 1986; 91: 1483-9.

26 Mahida YR, Patel S, Wu K, Jewell DP. Interleukin 2 receptor expression in inflammatory bowel disease. Clin Exp Immunol 1988; 74: 382-6.

27 Nelson DL, Rubin LA, Kurman CC, Fritz ME, Boutin B. An analysis of the cellular requirements for the production of soluble interleukin-2 receptors in vitro. $\mathcal{F}$ Clin Immunol 1986; 6: 114-9.

28 Bouchier IAD, Allen RN, Hodgson HJF, Keighley MRB Textbook of gastroenterology. London: Baillière Tindall, 1984: $940-6$

29 Ramadori G, Van Damme J, Rieder H, Meyer zum Buschenfelde KH. Interleukin 6, the third mediator of acute phase reaction, modulates hepatic protein synthesis in human and mouse. Comparison with interleukin 1 beta and tumor necrosis factor-alpha. Eur $\mathcal{f}$ Immunol 1988; 18: 1259 64

30 Andus T, Geiger T, Hirano T, Kishiomoto T, Heinrich PC Action of recombinant human interleukin 6 , interleukin Action of recombinant human interleukin 6, interleukin 1
beta and tumor necrosis factor alpha on the mRNA inducbeta and tumor necrosis factor alpha on the mRNA induc-
tion of acute-phase proteins. Eur $\mathcal{F}$ Immunol 1988; 18: 73946

31 Wood NC, Symons JA, Duff GW. Serum interleukin-2 receptor in rheumatoid arthritis: a prognostic indicator of disease activity? $\mathcal{F}$ Autoimmunity 1988; 1: 353-61. 